\title{
The effects of inhibitors of energy metabolism on the growth of one-cell rabbit ova to blastocysts in vitro
}

\author{
M. T. Kane* and N. J. Buckley \\ Department of Physiology, University College, Cork, Ireland
}

\begin{abstract}
Summary. Fertilized 1-cell rabbit ova were cultured in the presence of three oxidative phosphorylation inhibitors (cyanide, 2,4-dinitrophenol and oligomycin), two tricarboxylic acid (TCA) cycle inhibitors (malonate and fluoroacetate) and one glycolytic inhibitor (2-deoxyglucose). All three oxidative phosphorylation inhibitors killed ova at the 1-cell stage and the damage caused by each was similar. Malonate was non-toxic at all concentrations whereas some concentrations of fluoroacetate stopped growth at the 1-cell stage. This toxic effect could, in some circumstances, be reversed by the presence of acetate but not of glucose. 2-Deoxyglucose blocked only the transition from morula to blastocyst, and this was prevented by the addition of glucose to the medium; pyruvate, ribose, glycerol and $\mathrm{L}$ - $\alpha$-glycerol phosphate were ineffective. An active oxidative phosphorylation system and tricarboxylic cycle appear to be present and essential in the rabbit embryo from the 1-cell stage, but glycolysis may not be essential until blastocyst formation.
\end{abstract}

\section{Introduction}

Knowledge of the patterns of energy metabolism in preimplantation mammalian embryos is confined mainly to the mouse, and to a much lesser extent, the rabbit. Whitten (1957) and Brinster (1965) reported that lactate, pyruvate, phosphoenol pyruvate and oxaloacetate supported growth of 2-cell mouse ova to the blastocyst stage, but that glucose was not effective until the 8-cell stage. Subsequent research (reviewed by Wales, 1975) indicates that in the mouse ovum there is a functional tricarboxylic acid (TCA) cycle from the 1-cell stage, but a block to glycolysis for the first two or three cleavage divisions.

The work of Fridhandler and his associates (Fridhandler, Hafez \& Pincus, 1957; Fridhandler, 1961, 1968; Fridhandler, Wastila \& Palmer, 1967) indicated that the ability of rabbit embryos to carry out glycolysis developed only at the morula stage. Quinn \& Wales (1973), however, found clear evidence for some glycolytic capacity in cleavage-stage rabbit embryos, although this capacity was greatly increased at the blastocyst stage. The presence of a very active hexosemonophosphate shunt up to the morula stage has been indicated by carbon-labelling studies (Fridhandler, 1961; Brinster, 1968). An active TCA cycle was found in rabbit blastocysts (Fridhandler et al., 1967) but not in rabbit ova (Fridhandler et al., 1957), although Quinn \& Wales (1974) found evidence for TCA activity in the cleavage and blastocyst stages.

The purpose of the present study was to elucidate the importance of some of the different pathways of energy metabolism in rabbit ova by studying the effects of different metabolic inhibitors on the growth of 1-cell ova in culture. A similar study has been carried out by Thomson (1967) on 2-cell mouse ova.

\section{Materials and Methods}

New Zealand White and Dutch-belted does, 5-20 months of age, were induced to superovulate by treatment with FSH (twice daily s.c. injections for 3 days; $0.5 \mathrm{mg} /$ injection) followed 1 day later by simultaneous injection of HCG (150 units, intravenous) and artificial insemination. Fertilized ova (1-cell) were flushed from the oviducts $20-21 \mathrm{~h}$ after injection of HCG. The ova were washed to re-

*Present address: Department of Physiology, University College, Galway, Ireland. 
move oviductal debris and all those collected on one day were pooled and divided among the treatments of that day's experiment. The ova collected on one day constituted one replicate of an experiment or, in the case of Exps 1 and 2, one replicate of one inhibitor study. Usually at least three or more replicates were carried out per experiment or inhibitor study.

The eggs were cultured in $0.5 \mathrm{ml}$ droplets of medium under liquid paraffin in plastic tissue-culture dishes and were maintained in culture for 5 days at $38^{\circ} \mathrm{C}$ under a gas phase of $5 \% \mathrm{CO}_{2}$ in air. Ovum development was assessed microscopically every day. In all experiments the basic culture medium contained $1.5 \%$ crystallized bovine serum albumin (Sigma), $108 \mathrm{~mm}-\mathrm{NaCl}, 4.78 \mathrm{~mm}-\mathrm{KCl}, 1.71$ mM-CaCl $2.2 \mathrm{H}_{2} \mathrm{O}, 1 \cdot 19 \mathrm{~mm}-\mathrm{KH}_{2} \mathrm{PO}_{4}, 1 \cdot 19 \mathrm{~mm}-\mathrm{MgSO}_{4}, 25 \mathrm{~mm}-\mathrm{NaHCO}_{3}$, and 100 units penicillin $\mathrm{G}$ and $50 \mu \mathrm{g}$ streptomycin per $\mathrm{ml}$, and was supplemented with the amino acids, vitamins and trace elements of Ham's F10 medium (Ham, 1963; Kane \& Foote, 1970). This medium was used as a control treatment for all experiments and also as a basic medium to which the various inhibitors and substrates were added. All inhibitors were supplied by Sigma, except for potassium cyanide, obtained from May \& Baker.

Experiment 1 was a study of the effects of different concentrations of the oxidative phosphorylation inhibitors, potassium cyanide, 2,4-dinitrophenol and oligomycin. Cyanide inhibits cytochrome oxidase and other components of the respiratory chain (Mahler \& Cordes, 1971). Dinitrophenol uncouples oxidative phosphorylation and oligomycin inhibits the formation of ATP (Slater, 1963).

Experiment 2. Ova were cultured in the presence of TCA cycle inhibitors, sodium monofluoroacetate and sodium malonate. Malonate blocks the TCA cycle by inhibiting succinate dehydrogenase (Quastel, 1963). Fluoroacetate is first metabolized to fluorocitrate which then inhibits aconitase (Quastel, 1963).

Experiment 3. To determine whether the toxic effects of fluoroacetate were substrate reversible, ova were pretreated for $1 \mathrm{~h}$ at the 1-cell stage, either in fluoroacetate alone $\left(10^{-3} \mathrm{M}\right)$, in fluoroacetate plus sodium acetate $\left(5 \times 10^{-2} \mathrm{M}\right)$ or in fluoroacetate plus glucose $\left(10^{-2} \mathrm{M}\right)$. The eggs were then transferred to control medium and cultured for 5 days.

Experiment 4. The effects of different concentrations of the glycolytic inhibitor, 2-deoxyglucose, were examined. This is metabolized to 2-deoxyglucose-6-phosphate which blocks the enzyme glucose phosphate isomerase (Hochster, 1963).

Experiment 5. The stage of embryo growth at which the toxic effects of 2-deoxyglucose were exerted was determined. Ova were either cultured to the morula stage in control medium for 2 days and then transferred to medium with 2-deoxyglucose $\left(10^{-4} \mathrm{M}\right)$ for 3 days, or cultured in medium with 2-deoxyglucose for 2 days and then transferred to control medium for 3 days. The development obtained after these two treatments was compared with that of ova grown for 5 days in control medium, and ova grown for 5 days in medium with 2-deoxyglucose.

Experiment 6. The substrate reversibility of the 2-deoxyglucose effect was examined. Ova were cultured either in 2-deoxyglucose medium $\left(10^{-4} \mathrm{M}\right)$ or in media with 2-deoxyglucose and glucose, pyruvate, glycerol or ribose (all at $10^{-2} \mathrm{M}$ ).

Results obtained in experimental treatments were compared statistically with those in control treatments by the $\chi^{2}$ test.

\section{Results}

\section{Oxidative phosphorylation inhibitors (Exp. l)}

All three oxidative phosphorylation inhibitors stopped ovum growth at the 1-cell stage (Table 1). The inhibitor concentrations at which ovum death occurred correspond to those normally used to inhibit oxidative phosphorylation in other tissues (Mahler \& Cordes, 1971). The resulting cell damage affected almost every ovum and consisted of the formation of a clear space under the vitelline membrane but surrounding the cell cytoplasm, the 'pericytoplasmic space' (compare PI. 1, Fig. 2 with Pl. 1, Fig. 1). The formation of this pericytoplasmic space first became obvious as early as 20 min after placing ova in $10^{-3} \mathrm{M}$-cyanide. 
Table 1. Effects of oxidative phosphorylation inhibitors on growth of 1-cell rabbit ova

\begin{tabular}{|c|c|c|c|c|c|}
\hline \multicolumn{6}{|l|}{ Potassium cyanide } \\
\hline Inhibitor conc. (M) & 0 & $10^{-3}$ & $10^{-4}$ & $10^{-5}$ & $10^{-6}$ \\
\hline No. of ova & 34 & 36 & 34 & 34 & 34 \\
\hline$\%$ Blastocysts & 47 & $0 \dagger, * * *$ & $0 \nmid, * * *$ & 56 & 65 \\
\hline \multicolumn{6}{|l|}{ 2,4-Dinitrophenol } \\
\hline Inhibitor conc. (M) & 0 & $10^{-3}$ & $10^{-4}$ & $10^{-5}$ & $10^{-6}$ \\
\hline No. of ova & 30 & 33 & 32 & 35 & 43 \\
\hline$\%$ Blastocysts & 70 & $0 \nmid \cdot * * *$ & $34^{*}$ & 60 & 47 \\
\hline \multicolumn{6}{|l|}{ Oligomycin } \\
\hline Inhibitor conc. $(\mu \mathrm{g} / \mathrm{ml}) \ddagger$ & & 0 & 1 & 0.2 & 0.04 \\
\hline No. of ova & & 31 & 29 & 33 & 29 \\
\hline$\%$ Blastocysts & & 52 & $0+, * * *$ & $0 \dagger, * * *$ & $14 * *$ \\
\hline
\end{tabular}

Significantly different from 0 concentration of inhibitor: ${ }^{*} P<0.05 ;{ }^{* *} P<0.01 ; * * * P<0.001$. $\dagger$ All these ova were killed at the 1-cell stage.

$\ddagger$ Given in $\mu \mathrm{g} / \mathrm{ml}$ because the oligomycin used was a mixture of $A$ and $B$ isomers $(1 \mu \mathrm{g} / \mathrm{ml}$ approximately $=2.5 \times 10^{-6} \mathrm{M}$ ).

Table 2. Effects of Krebs cycle inhibitors on growth of 1-cell rabbit ova

\begin{tabular}{lccccc}
\hline Sodium monofluoroacetate & & & & & \\
$\quad$ Inhibitor conc. (M) & 0 & $10^{-2}$ & $3 \times 10^{-3}$ & $10^{-3}$ & $10^{-4}$ \\
No. of ova & 70 & 69 & 65 & 58 & 64 \\
$\%$ Blastocysts & 63 & $0 \dagger^{* *}$ & $0 f^{* *}$ & $0^{*}$ & $28^{*}$ \\
Sodium malonate & & & & & \\
Inhibitor conc. (M) & 0 & $10^{-2}$ & $10^{-3}$ & $10^{-4}$ & \\
No. of ova & 27 & 29 & 23 & 27 & \\
\% Blastocysts & 46 & 45 & 43 & 67 & \\
\hline
\end{tabular}

Significantiy different from 0 concentration of inhibitor: ${ }^{*} P<0.001$.

$\dagger$ All these ova were killed at the 1-cell stage.

\section{TCA cycle inhibitors (Exps 2 and 3)}

There was no sign of any toxic effect of sodium malonate (Table 2). However, sodium monofluoroacetate completely prevented development at concentrations of $10^{-2} \mathrm{M}$ to $10^{-3} \mathrm{M}$ and resulted in a significant drop in blastocyst formation at $10^{-4} \mathrm{M}$ (Table 2). Growth was stopped at the 1-cell stage in $10^{-2}$ and $3 \times 10^{-3} \mathrm{M}$-sodium monofluoroacetate, concentrations comparable to those which have been used by previous workers to block the TCA cycle and cause citrate accumulation in other tissues (Liebecq \& Peters, 1949; Buffa, Peters \& Wakelin, 1951). This effect of fluoroacetate was specifically prevented by acetate but not by glucose (Exp. 3, Table 3). Preliminary experiments in which ova were pretreated for $6 \mathrm{~h}$ with fluoroacetate before transfer to inhibitor-free media showed that $5 \times 10^{-2} \mathrm{M}$ acetate would not protect ova against $10^{-3} \mathrm{M}$-fluoroacetate for that length of time. This may be partly due to a toxic effect of high concentrations of acetate, because other preliminary trials showed that ova cultured for 5 days in $5 \times 10^{-2} \mathrm{M}$-acetate did not develop to morulae or blastocysts. This effect of acetate was not due to osmolarity effects because the osmotic effect of the added sodium acetate was compensated for by the omission of equimolar quantities of $\mathrm{NaCl}$.

\section{Glycolytic inhibitor (Exps 4, 5 and 6)}

There was a complete failure of blastocyst formation when concentrations of $10^{-2}$ to $10^{-4} \mathrm{M}-2-$ deoxyglucose were used (Exp. 4, Table 4). Most of the ova reached the morula stage but none progressed to the blastocyst stage. A concentration of $2.4 \times 10^{-3} \mathrm{M}$ has been shown to inhibit growth of embryonic chicken heart fibroblasts in tissue culture (Hochster, 1963). The inhibitory effect of 2deoxyglucose was specific to the period of blastocyst formation (Exp. 5, Table 5): ova cultured to the 
Table 3. Effects of $5 \times 10^{-2} \mathrm{M}$-acetate and $10^{-2} \mathrm{M}$ glucose on the inhibition by $10^{-3} \mathrm{M}$-fluoroacetate of growth of 1-cell rabbit ova

\begin{tabular}{lcccc}
\hline & & & \multicolumn{3}{c}{$\begin{array}{c}\text { Fluoro- Fluoro- } \\
\text { acetate } \\
+\end{array}$} & $\begin{array}{c}\text { Control } \\
\text { acetate } \\
+\end{array}$ \\
& medium & $\begin{array}{c}\text { Fluoro- } \\
\text { acetate }\end{array}$ & $\begin{array}{c}+ \\
\text { acetate }\end{array}$ & glucose \\
\hline $\begin{array}{l}\text { No. of ova } \dagger \\
\% \text { Blastocysts }\end{array}$ & 46 & 44 & 47 & 43 \\
\hline
\end{tabular}

Significantly different from control medium, $* P<0.001$.

$\dagger$ Pretreated for $1 \mathrm{~h}$ at the 1-cell stage and then transferred to control medium for 5 days.

Table 5. Effect of $10^{-4} \mathrm{M}$-2-deoxyglucose added at different stages of culture on growth of 1-cell rabbit ova to blastocysts

\begin{tabular}{|c|c|c|c|c|}
\hline & $\begin{array}{l}\text { Control } \\
\text { medium } \\
\text { (5 days) }\end{array}$ & $\begin{array}{l}\text { Deoxy- } \\
\text { glucose } \\
\text { (5 days) }\end{array}$ & $\begin{array}{c}\text { Deoxy- } \\
\text { glucose } \\
\text { (2 days) } \\
+ \\
\text { control } \\
\text { medium } \\
\text { (3 days) }\end{array}$ & $\begin{array}{c}\text { Control } \\
\text { medium } \\
\text { (2 days) } \\
+ \\
\text { deoxy- } \\
\text { glucose } \\
\text { (3 days) }\end{array}$ \\
\hline $\begin{array}{l}\text { No. of ova } \\
\% \text { Blastocysts }\end{array}$ & $\begin{array}{l}36 \\
67\end{array}$ & $\begin{array}{c}40 \\
0^{*}\end{array}$ & $\begin{array}{l}29 \\
59\end{array}$ & $\begin{array}{c}32 \\
0^{*}\end{array}$ \\
\hline
\end{tabular}

Significantly different from control medium, ${ }^{*} P<0.001$.
Table 4. Effect of a glycolytic inhibitor, 2-deoxyglucose, on growth of 1-cell rabbit ova

\begin{tabular}{lccccc}
\hline Inhibitor conc. (M) & 0 & $10^{-2}$ & $10^{-3}$ & $10^{-4}$ & $10^{-5}$ \\
No. of ova & 41 & 44 & 40 & 41 & 36 \\
$\%$ Morulae & 56 & 50 & 68 & 49 & 64 \\
$\%$ Blastocysts & 44 & $0^{*}$ & $0^{*}$ & $0^{*}$ & 25 \\
\hline
\end{tabular}

Significantly different from 0 concentration of inhibitor: ${ }^{*} \boldsymbol{P}<0.001$.

Table 6. Effects of different substrates on the inhibition by $10^{-4} \mathrm{M}$-2-deoxyglucose of growth of 1-cell rabbit ova to blastocysts

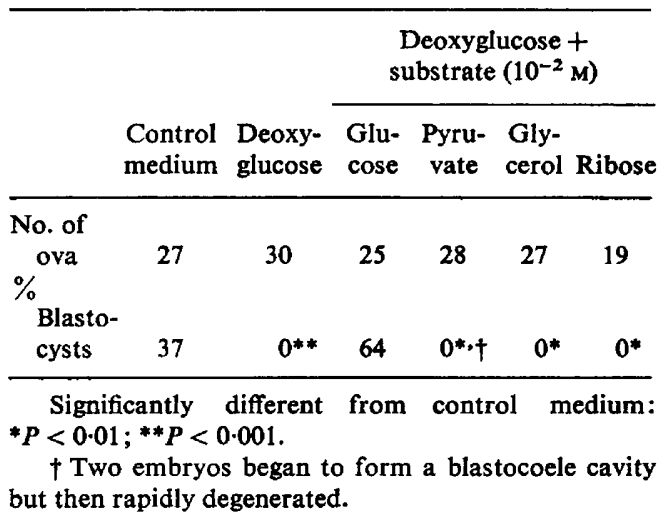

morula stage in medium with inhibitor developed to blastocysts when transferred to control medium, whereas ova cultured in control medium to the morula stage were arrested at that stage when transferred to medium with inhibitor.

The inhibitory effect of $10^{-4} \mathrm{M}$-2-deoxyglucose on blastocyst formation was completely reversed by the addition of $10^{-2} \mathrm{M}$-glucose but was not prevented by pyruvate, glycerol or ribose (Exp. 6, Table 6), L- $\alpha$-glycerol phosphate, or by ribose, pyruvate and glycerol in combination (data not shown, separate trial).

\section{Discussion}

The results with cyanide, 2,4-dinitrophenol and oligomycin provide strong evidence for an essential role for the process of oxidative phosphorylation in normal growth of the fertilized 1-cell rabbit egg. These findings are in agreement with the work of Fridhandler $e t$ al. (1957) who found, using Cartesian diver techniques, that cyanide reduced to near zero the oxygen uptake of 2-8-cell rabbit ova and advanced blastocysts. Pincus (1941) reported that cyanide inhibited growth of 3-day rabbit embryos

\section{PLATE 1}

Fertilized 1-cell rabbit ova, collected about $20 \mathrm{~h}$ after HCG injection and placed in medium containing $10^{-3} \mathrm{M}-\mathrm{KCN}$. Ova were photographed directly from the culture dish.

Fig. 1. Two ova at the start of treatment with $\mathrm{KCN} . \times 310$.

Fig. 2. Five ova after $6 \mathrm{~h}$ of treatment with $\mathrm{KCN}$. The vitelline membranes of each egg appear to have separated from the cytoplasmic contents to form a 'pericytoplasmic space' (PC). $\times 250$. 


\section{PLATF I}
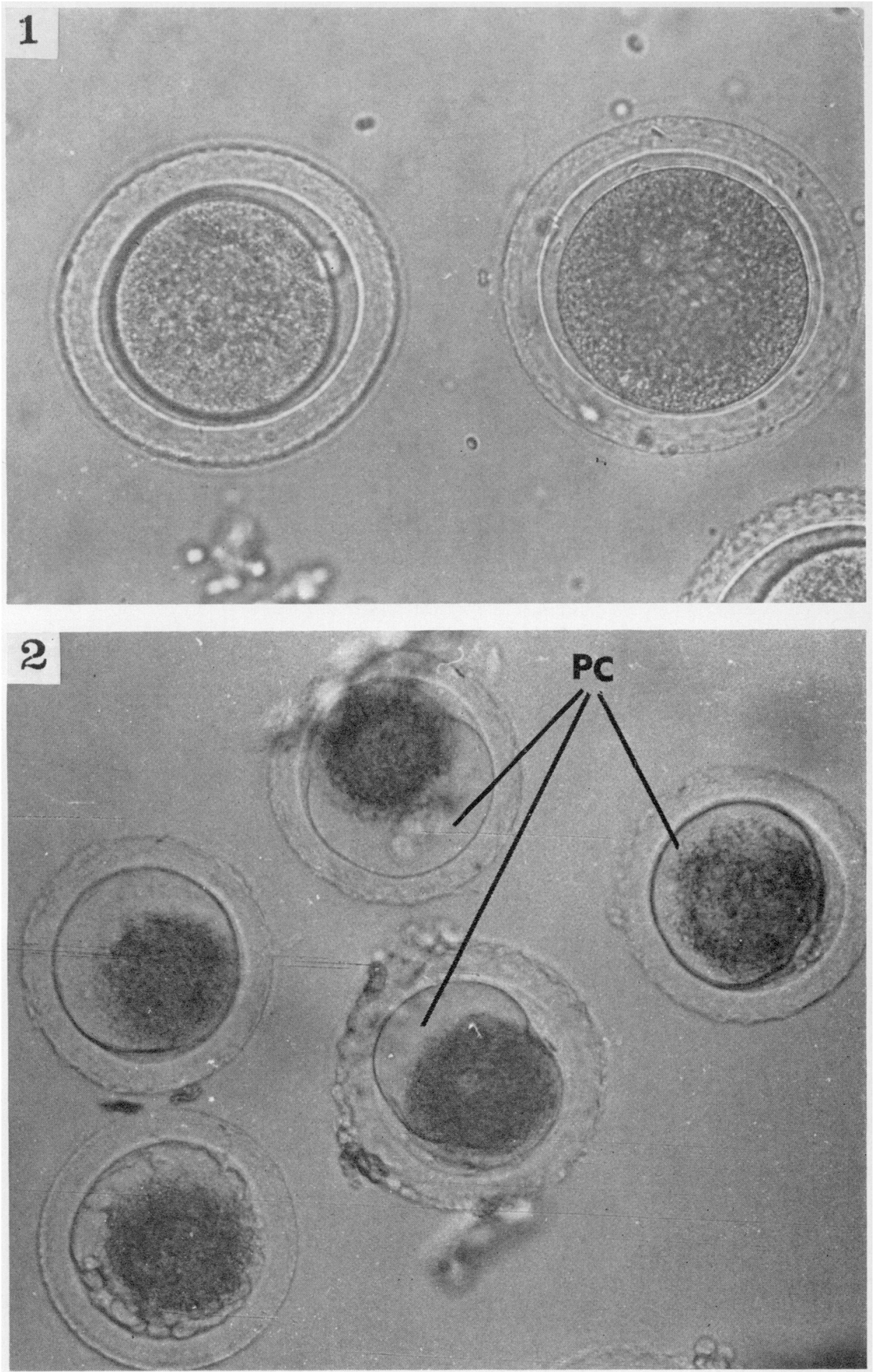
cultured in serum and Thomson (1967) found that cyanide and 2,4-dinitrophenol caused degeneration of 2-cell mouse ova during the first $24 \mathrm{~h}$ of culture.

The gross appearance of the damage caused by these three inhibitors in the present study was the consistent formation of a 'pericytoplasmic' space or vacuole, apparently because of a rapid breakdown of the normal relationship of the cytoplasmic contents to the vitelline membrane. We have observed similar types of damage from other causes but never with anything like the same frequency. The toxicity of oligomycin and dinitrophenol is unlikely to be due to effects on cation transport because (i) all three oxidative phosphorylation inhibitors caused the same type of damage and (ii) ouabain, a specific inhibitor of a $\mathrm{Na}^{+} / \mathrm{K}^{+}$-activated ATPase system (Post, Merritt, Kinsolving \& Albright, 1960), does not cause similar damage and does not stop growth at the 1-cell stage, although it does prevent growth to the blastocyst stage (N. J. Buckley \& M. T. Kane, unpublished data).

The TCA cycle inhibitors, fluoroacetate and malonate, gave contradictory results in that fluoroacetate stopped ovum growth at the 1-cell stage whereas malonate was not toxic even at concentrations as high as $10^{-2} \mathrm{M}$, a finding similar to that of Thomson (1967) for 2-cell mouse ova. We feel that the failure of malonate to exert a toxic effect may be partly due to failure to penetrate the ovum in sufficient quantities because of the dicarboxylic nature of the malonate molecule. There is some evidence that the entry of malonate into mitochondria is dependent on a carrier system (Pressman, 1970). Evidence for the presence of such a carrier system for rabbit embryo mitochondria is lacking but Wales \& Biggers (1968) have shown that malate, another dicarboxylic acid, appears to enter mouse ova by an active process.

The fluoroacetate results when taken in conjunction with those of the oxidative phosphorylation experiments strongly indicate that the TCA cycle is both present and essential for fertilized 1-cell rabbit eggs. This conclusion is strengthened by the fact that acetate prevented the toxic effects of pretreatment with fluoroacetate whereas glucose did not. A number of studies have shown the presence of TCA cycle metabolism in the mouse ovum as early as the 2-cell stage (Wales \& Whittingham, 1970; Quinn \& Wales, 1971 ; Barbehenn, Wales \& Lowry, 1974) and TCA cycle activity in the early cleavage stages of the rabbit ovum has also been demonstrated (Quinn \& Wales, 1974). The fact that acetate overcame the toxic effects of pretreatment with fluoroacetate, whereas glucose did not, suggests that even if glycolysis is active during early cleavage insufficient glucose is being metabolized to provide enough energy for ovum growth when the TCA cycle is blocked by fluoroacetate. This idea is supported by the results obtained with 2-deoxyglucose. Ova cultured in concentrations of 2-deoxyglucose as low as $10^{-4} \mathrm{M}$ developed to the morula stage but remained arrested at that stage. Similar results were obtained for 2-cell mouse ova by Thomson (1967) and LutwakMann, Hay \& New (1969) reported that treatment of 6-day rabbit blastocysts in vitro with 2-deoxyglucose resulted in damage to the embryonic disc and the trophoblast. Our experiments (Exp. 5) showed that the block to development exerted by 2-deoxyglucose is specific to the stage of blastocyst formation. Fridhandler (1961), who measured $\mathrm{CO}_{2}$ evolution from radiolabelled glucose, found negligible rates of glycolysis under anaerobic conditions in rabbit embryos until the blastocyst stage was reached. Quinn \& Wales (1973) found that while glucose was metabolized to acetate, pyruvate and lactate by cleavage stages of the rabbit embryo, accumulation of these compounds was greatly increased at the blastocyst stage. All these results indicate a relatively minor role for glycolysis until the blastocyst stage.

The essential role of glucose at the time of blastocyst formation is not clear. It can hardly be for amino acid formation because a full range of amino acids was present in the media used in our experiments. This role is also unlikely to be related solely to energy production, pentose formation or the production of $\mathrm{L}-\alpha$-glycerol phosphate for triglyceride formation, because pyruvate, ribose and glycerol, alone and in combination, and $\mathrm{L}-\alpha$-glycerol phosphate alone were unable to protect against the effects of 2-deoxyglucose. It is, however, possible that the failure of these substances to act protectively may have been due to an inability of one or more of them to permeate the zygote. Another possible explanation is that the glucose may be used itself or in the form of other hexoses for the production of glycoproteins or of glycolipids which are involved in cell-to-cell interactions (Hughes, 1975). It is possible that 2-deoxyglucose may be incorporated into some of these compounds and interfere with their function by distortion of their structure. The finding of Van Blerkom, Manes \& 
Daniel (1973) that the appearance of tight cell junctions in the rabbit embryo is coincidental with the onset of blastulation may be relevant here.

The general picture of energy metabolism in the rabbit embryo to emerge from these studies and from those of other workers is that even at the 1-cell stage an active TCA cycle and oxidative phosphorylation system are present and essential for ovum growth, but glycolysis does not appear to become essential until the onset of blastulation. These findings appear to be valid for the mouse and may also apply to other species.

This research was supported by a grant to M.T.K. from the Medical Research Council of Ireland.

\section{References}

BARBEHENN, E.K., WALES, R.G. \& LOWRY, O.H. (1974) The explanation for the blockade of glycolysis in early mouse embryos. Proc. natn. Acad. Sci. U.S.A. 71, 1056-1060.

BRINSTER, R.L. (1965) Studies on the development of mouse embryos in vitro. 11. The effect of energy source. J. exp. Zool. 158, 59-68.

BRINSTER, R.L. (1968) Carbon dioxide production from glucose by the preimplantation rabbit embryo. Expl Cell Res. 51, 330-334.

Buffa, P., Peters, R.A. \& Wakelin, R.W. (1951) Biochemistry of fluoroacetate poisoning. Isolation of an active tricarboxylic acid fraction from poisoned kidney homogenates. Biochem. J. 48, 467-477.

FRIDHANDLER, L. (1961) Pathways of glucose metabolism in fertilized rabbit ova at various preimplantation stages. Expl Cell Res. 22, 303-316.

FridHANDLER, L. (1968) Intermediary metabolic pathways in preimplantation rabbit blastocysts. Fert. Steril. 19, 424-434.

Fridhandler, L., Hafez, E.S.E. \& Pincus, C. (1957) Developmental changes in the respiratory activity of rabbit ova. Expl Cell Res. 13, 132-139.

Fridhandler, L., Wastila, W.B. \& Palmer, W.M (1967) The role of glucose in metabolism of the developing mammalian preimplantation conceptus. Fert. Steril. 18, 819-830.

HAM, R.G. (1963) An improved nutrient solution for diploid Chinese hamster and human cell lines. Expl Cell Res. 29, 515-526.

Hochster, R.M., (1963) Hexose and pentose analogues. In Metabolic Inhibitors, Vol. I, pp. 131-152. Eds R. M. Hochster \& J. H. Quastel. Academic Press, New York.

Hughes, R.C. (1975) Complex carbohydrates of mammalian cell surfaces and their biological roles. Essays in Biochemistry. 11, 1-36.

KANE, M.T. \& Foore, R.H. (1970) Culture of two- and four-cell rabbit embryos to the expanding blastocyst stage in synthetic media. Proc. Soc. exp. Biol. Med. 133, 921-925.

LiebecQ, C. \& Peters, R.A. (1949) The toxicity of fluoroacetate and the tricarboxylic acid cycle. Biochim. biophys. Acta 3, 215-230.

Lutwak-ManN, C., HaY, M.F. \& New, D.A.T. (1969) Action of various agents on rabbit blastocysts in vivo and in vitro. J. Reprod. Fert. 18, 235-257.

MAHLER, H.R. \& CoRDES, E.H. (1971) Biological Chemistry. Harper and Row, New York.
Pincus, G. (1941) Factors controlling the growth of rabbit blastocysts. Am. J. Physiol. 133, 412413.

Post, R.L., Merritt, C.R., Kinsolving, C.R. \& Albright, C.D. (1960) Membrane adenosine triphosphatase as a participant in the active transport of sodium and potassium in the human erythrocyte. J. biol. Chem. 235, 1796-1802.

Pressman, B.C. (1970) Energy-linked transport in mitochondria. In Membranes of Mitochondria and Chloroplasts, pp. 213-250. Ed. E. Racker. Van Nostrand Reinhold Company, New York.

QUASTEL, J.H. (1963) Inhibitions in the citric acid cycle. In Metabolic Inhibitors, Vol. II, pp. 473-502. Eds R. M. Hochster \& J. H. Quastel. Academic Press, New York.

QuinN, P. \& Wales, R.G. (1971) Fixation of carbon dioxide by preimplantation mouse embryos in vitro and the activities of enzymes involved in the process. Aust. J. biol. Sci. 24, 1277-1290.

QuINN, P. \& W ALES, R.G. (1973) The in vitro metabolism of [U- ${ }^{14} \mathrm{C}$ ]glucose by the preimplantation rabbit embryo. Aust. J. biol. Sci. 26, 653-667.

QuinN, P. \& Wales, R.G. (1974) Fixation of carbon dioxide by preimplantation rabbit embryos in vitro. J. Reprod. Fert. 36, 29-39.

SLATER, E.C. (1963) Uncouplers and inhibitors of oxidative phosphorylation. In Metabolic Inhibitors, Vol. II, pp. 503-516. Eds R. M. Hochster \& J. H. Quastel. Academic Press, New York.

THOMSON, J.L. (1967) Effect of inhibitors of carbohydrate metabolism on the development of preimplantation mouse embryos. Expl Cell Res. 46, 252-262.

Van Blerkom, J., Manes, C. \& Daniel, J.C., JR (1973) Development of preimplantation rabbit embryos in vivo and in vitro. I. An ultrastructural comparison. Devl Biol. 35, 262-282.

WALES, R.G. (1975) Maturation of the mammalian embryo; biochemical aspects. Biol. Reprod. 12, 66-81.

Wales, R.G. \& Biggers, J.D. (1968) The permeability of two- and eight-cell mouse embryos to L-malic acid. J. Reprod. Fert. 15, 103-111.

Wales, R.G. \& Whittingham, D.G. (1970) Metabolism of specifically labelled pyruvate by mouse embryos during culture from the two-cell stage to the blastocyst. Aust. J. biol. Sci. 23, 877-887.

WhitTeN, W.K. (1957) Culture of tubal ova. Nature, Lond. 179, 1081-1082. 